DOI https://doi.org/10.18551/rjoas.2018-09.01

\title{
STRATEGY OF LOCAL RESOURCES-BASED SOCIAL EMPOWERMENT TO ACHIEVE FOOD SECURITY AT THE BORDERS OF INDONESIA-MALAYSIA
}

\author{
Suryana Nia Kurniasih*, Eko Hary Pudjiwati \\ Faculty of Agriculture, Borneo University of Tarakan \\ ${ }^{*}$ E-mail: zlynia@gmail.com
}

\begin{abstract}
In fact, the development of food security is social empowerment, which means that it improves self-supporting (independence) and capacity of the communities to play their roles in order to ascertain food availability, food distribution, and food consumption from time to time. Social empowerment can be striven for through improving human resources capacity in managing local potencies. Objective of this research was to formulate the strategy of social empowerment in order to achieve food security at the borders of Indonesia-Malaysia. Location of the research was at the North Sebatik Subdistrict of Nunukan Regency. Method of the data analysis used SWOT analysis. Results of the research showed that the strategy of local resources-based social empowerment to achieve food security at the borders of Indonesia-Malaysia is strategy I, Aggressive Strategy, by taking opportunity and strength, which include: developing local potency-based empowerment program, developing agricultural-based industry by developing derivative product to increase added value, optimizing the extension performance, increasing number and improving quality of the crops product and horticulture.
\end{abstract}

\section{KEY WORDS}

Social empowerment, local resources, food security, borders.

Rapid growth of population in Indonesia has become great threat in supplying national foods. It is due to the increase number of population is in accordance with the increase demand for foods along with the economy growth, purchasing power of the public, and the change of taste. Dynamic from the demand side causes the needs for food increase that relates to number, quality, variability, and security. Besides that, the problem of foods occur due to limited natural resources, means and infrastructure in food sector, strict competition with imported products, and greater proportion of the poor (The Board of Food Security, 2010).

Jokolelono (2011) suggested that in developing countries or in under-developed countries, two-third or more populations live at the suburban and make their living in agricultural sector. One of efforts to bring it into reality is improving food security due to food is the basic needs for human and how to fulfill it is the human right. So, it is no exaggeration to say that high food security is guarantee of health, prosperity, and welfare of a country. Local resources potency as food source must be explored optimally in order to increase food availability to fulfill the needs for foods consumption, which must be qualified, assorted, and reachable at the household level, to raise the farmer's income, and to support natural resources conservation.

Actually, the development of food security is social empowerment, which means that it improves self-supporting (independence) and capacity of the communities to play their roles in order to ascertain food availability, food distribution, and food consumption from time to time. Social empowerment and food security at the North Sebatik Subdistrict is still in medium level (Suryana, 2017)

Geographically, North Sebatik Subdistrict has area, which is divided in two, a part area belongs to Indonesia and the other part belongs to Malaysia. This island is one of the outer islands that should become the main priority of development due to it is adjacent to the neighboring country, Malaysia. Sebatik Island has much potency in various sectors, such as agriculture, plantation, fishery, and tourism (Suryana, 2017). 
Agricultural products as food source have not well managed, limited off farm industry has caused the farmers prefer to sell their products to the neighboring country even in lower price, quantity and quality of the foodstuffs of their own products have not fulfilled the needs of community continuously and the increase of human resources quality through extension has not optimal yet, cause the accessibility to qualified and varying foods have not been fulfilled optimally.

Objectives of the research were: (1) to study both external and internal factors, which affect social empowerment in order to achieve food security at the borders, and (2) to formulate the strategy of social empowerment in order to achieve food security at the borders of Indonesia-Malaysia.

\section{LITERATURE REVIEW}

Local Resources. Local resources or local potency are ability or strength or power of a region that can be developed to bring about benefit/advantage for the related region (Kasmini 2017). Local potency can be assessed from some elements, such as social capital, social system, and cultural system. Social capital is resources, which emerge as a result of interaction in a community among individual or institution that create emotional bond, such as trust, reciprocal relationship, and social network, values and norms, which establish social structure in order to coordinate and cooperate in achieving the goal. Social system is a complex of activities and actions, which have specific pattern that derived from human in society, for example, social cohesion, social institution, as well as social organization. Cultural social is a part of culture as a complex of ideas, initiatives, concepts, values, norms, and regulations. Those ideas are unseparated, but they close to each other, interrelated to become a system.

Natural resources play important role for human life. For communities in Indonesia, natural resources do not only have economic value, but also have social, cultural, and political meanings (Hidayat, 2011).

Human resources play their roles in human resources change in order to reach the success of empowerment process. Human capital is marked by adequate educational level, which is supported by educational means and infrastructure development that lead to empowerment development and, of course, it will significantly affect on social independence or self-supporting of the community (Widjajanti, 2011). The concept that has been developed by Romer (1990) suggested that human capital as antecedent of the empowering process. Huseini (1999) described that human capital is reflection of education, experience, intuition, and expertise.

Social resource is important facilitator in economic development. Social capital, which is formed in accordance with social and economic activities in the past are viewed as factor that could enhance economic development and it may strengthen the developmental effectiveness if it is applied appropriately (Suharto and Yuliani, 2005). Based on those explanations, it can be concluded that social capital is a norm or value, which has been mutually understood by community that will strengthen positive social network, mutualism cooperation, generate great concern and high solidarity, as well as enhance mutual trustworthiness in order to achieve the goals (Widjajanti, 2011).

Social Empowerment. Basically, social empowerment concept is a development concept, which is centered on community in order to grow and improve creative initiatives of the community in handling problems and developing the superior potencies continuously by improving social ability to develop products of the development to better direction continuously (Efendi.et.al, 2014). Social empowerment is intended to create independent individual and community. Such independence includes independence in thinking, taking action, and controlling what they have done. Social independence is a condition, which is experienced by the community that is marked by their ability to think, decide, and do something appropriately in order to solve the problem by using their own abilities. The related abilities refer to cognitive, conative, psychomotoric, and affective, as well as physical/material resources. Of course, in order to achieve social independence, it requires learning process. 
Communities who have attended the learning process will gradually gain power, strength, and abilities, which are useful in decision-making process independently (Widjajanti, 2011).

Sumodiningrat (2000) suggested that social empowerment, which is marked by independence, will be achieved through social empowerment process. Social empowerment may be brought into reality through active participation of the community, which is facilitated by the empowerment agents. The main targets of social empowerment are individuals who are weak, powerless, have no strengths or abilities to access productive resources, or the marginalized community in the development. The final goal of the social empowerment process is to create independent individuals in the community in order to increase their living standards of their families and to optimize their own resources.

Social empowerment can be brought into reality through active participation of the community, which is facilitated by the empowerment agents. The main targets of social empowerment are individuals who are weak, powerless, have no strengths or abilities to access productive resources, or the marginalized community in the development. The final goal of the social empowerment process is to create independent individuals in the community in order to increase their living standards of their families and to optimize their own resources (Mardikanto, 2010).

Food Security. Food security is the availability of foods, both quantity and quality, which can be accessed by the community, not only economically but also locally, in order to establish productive and healthy life. Therefore, it can be concluded that there are three components in the definition of food security, which include food availability, food accessibility, and food absorption (Suryana, 2017).

Increasing food security is the main priority in development due to foods is the most basic needs for human, so that food plays important role in the national economic growth. Food security means the foods are available in sufficient quantity and quality, well distributed along with affordable price, and safe to eat by everyone in order to support their activities during the day. Therefore, food security covers both household and national levels (Rachman, 2002).

Moreover, Rachman (2002) suggested that in globalization era and free-trade, which is highly competitive in international market, Indonesia has faced heavy threats in formulating food policy that coud fulfill the needs for foods of the Indonesian people. Such food policies include efforts to sustain and enhance availability of various food commodities and effort to improve diversification of the consumed foods. Under limited resources, some policies must be applied to increase foods that relates to how to sustain food security, for instance, using various resources to produce competitive food commodities, both in price and quality, against the imported products. In such condition, food production activity must be oriented to international market.

\section{METHODS OF RESEARCH}

Based on objective of the research, mixed methods were used as research approach by combining quantitative and qualitative approaches (Creswell, 2010).

The research was conducted at North Sebatik Subdistrict of Nunukan Regency. North Sebatik Subdistrict lies at the East end of Nunukan Regency, Indonesia. It lies on Sebatik Island, which is divided in two regions, a part belongs to Indonesia, and other part belongs to Sabah, Malaysia.

Data of the research used primary and secondary data, which derived from diverse sources.

- Primary data will be derived from questionnaires and interview with farmers, breeders, and fisherman, as well as depth interview with public figures, farmer group leader, extension agents, and the headman.

- Secondary data will be derived from information, which is provided by official governmental institutions that are related to activities of the research, such as: Central Bureau of Statistics, Agency for Regional Development, Department of 
Agriculture, Animal Husbandry, and Crops, as well as Department of Fishery and

Oceanic Affairs, and other institutions, which have relevant data.

Data of the research was collected through some methods, such as observation in the field, interview, questionnaire distribution and depth-interview. Data documentation process will be done in the form of written documentation and audio records to make sure validity of the data.

Populations of the research were members of farmer group at the North Sebatik Subdistrict, which comprised of 195 farmers. Samples were taken by using Simple Random Sampling, a sample determination method that was taken randomly regardless of the members' strata (Sugiono, 2012). Numbers of sample in the research were 65 farmers.

Data was analyzed using SWOT (Strengths, Weaknesses, Opportunities, Threats) analysis. It also used Internal Factor Evaluation and External Factor Evaluation. Internal factor evaluation (IFE) is used to study the internal factors in a company/organization that related to strength and weakness, which are considered important. External factor evaluation (EFE) is used to study the external factors in a company/organization that related to opportunity and threat (David 2006). The next stages are as follow: 1) Identifying and studying deeply against each factor that becomes strength and weakness (internal factor), as well as opportunity and threat (external factor) of the social empowerment in order to improve food security at the borders of Indonesia-Malaysia; 2) Weighing each factor by using paired comparison method. Score is given on the paired comparison between two factors relatively in accordance with level of importance; 3) Ranking 1 to 4 on each internal factor, whereas 4 is the main strength, 3 is low strength, 2 is low weakness, and 1 is the main weakness; 4) Multiplying weight of each factor with the rank on each factor to obtain weighted score; and 5) Counting up all the weighted scores to obtain total weighted scores; 6) SWOT (StrengthsWeaknesses-Opportunities-Threats) matrix. After conducting both external and internal environmental analysis, it brings about opportunity and threat as external strategic factor, while strength and weakness are considered as internal strategic factor. Those factors are arranged in SWOT matrix in order to facilitate the alternative strategic formulation by adjusting between strength and opportunity (SO strategy), strength and threat (ST strategy), weakness and opportunity (WO strategy), as well as weakness and threat (WT strategy).

\section{DISCUSSION OF RESULTS}

Internal and external analyses were used to find out strategic factors, which affect on social empowerment to achieve food security at the North Sebatik Subdistrict. Internal analysis is used to study the strength and weakness factors, while external factor is used to study opportunity and threat factors.

Strength factor of the internal environment has total score 1.32 that includes farmers who produce foodstuffs by the highest score 0.36 , the second strength are potency of plantation and agricultural yields by score 0.33 , and followed by the factor of farmer group and association of the farmer group (GAPOKTAN) by score 0.24 , social empowerment program by score 0.22 , agricultural extension agent by score 0.12 , and wide farming land (> 0.2 ha) by score 0.05 .

Meanwhile, other factor of internal environment is weakness factor, which has total score 1.03, the weakness factors comprise of infrastructural facilities of the farm operations that have not completed yet by score 0.36 , fluctuative yield of foods production by score 0.24 , low diversification of foods by score 0.14 , low independence of the farmers by score 0.08 , and low participation of the farmers in social empowerment program by score 0.03 .

Opportunity factor of the external environment has total score 1.34 that includes utilizing regional potency, which has not optimal and has not been developed by the highest score 0.39 , and then expansion of the market (abroad) by score 0.36 , increasing needs for food by score 0.33 , governmental assistance by score 0.08 , and District-owned Corporation (BUMDES) by score 0.08 . 
Table 1 - Weight and Rank of Internal Strategic Factor on the Process of Local Resources-Based Social Empowerment to Achieve Food Security at the North Sebatik Subdistrict

\begin{tabular}{|c|c|c|c|}
\hline \multirow[b]{2}{*}{$\begin{array}{l}\text { Internal Strategic Factor } \\
\text { Strengths (S): } \\
\text { - Farmers produce foodstuffs } \\
\text { - } \quad \text { Potency of plantation and agricultural yields } \\
\text { - } \quad \text { Wide farming land owned by the farmer }(>2 \mathrm{Ha}) \\
\text { - Social empowerment program } \\
\text { - Agricultural extension agent }\end{array}$} & Rank & Weight & Score \\
\hline & $\begin{array}{l}0.12 \\
0.11 \\
0.12 \\
0.05 \\
0.11 \\
0.06\end{array}$ & $\begin{array}{l}3 \\
3 \\
2 \\
1 \\
2 \\
2\end{array}$ & $\begin{array}{l}0.36 \\
0.33 \\
0.24 \\
0.05 \\
0.22 \\
0.12\end{array}$ \\
\hline & & & 1.32 \\
\hline $\begin{array}{l}\text { Weaknesses }(\mathrm{W}) \text { : } \\
\text { - } \quad \text { Empowerment program has not completely conformed to the needs of } \\
\text { - } \quad \text { Incomplete infrastructural facilities of the farm operations } \\
\text { - } \quad \text { Fluctuative yield of foods production } \\
\text { - Low participation of the farmers in social empowerment program } \\
\text { - Low diversification of foods } \\
\text { - Low independence of the farmers }\end{array}$ & $\begin{array}{l}0.09 \\
0.12 \\
0.08 \\
0.03 \\
0.07 \\
0.04\end{array}$ & $\begin{array}{l}2 \\
3 \\
3 \\
1 \\
2 \\
2\end{array}$ & $\begin{array}{l}0.18 \\
0.36 \\
0.24 \\
0.03 \\
0.14 \\
0.08\end{array}$ \\
\hline & 1.00 & & 1.03 \\
\hline External Strategic Factor & Rank & Weight & Score \\
\hline 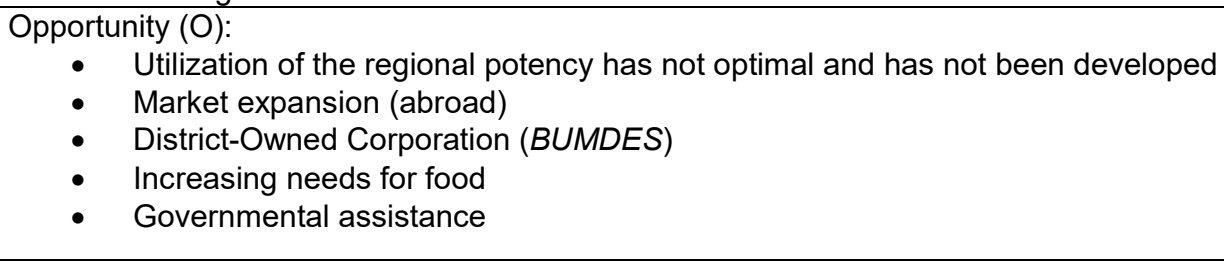 & $\begin{array}{l}0.13 \\
0.12 \\
0.08 \\
0.11 \\
0.09\end{array}$ & $\begin{array}{l}3 \\
3 \\
1 \\
3 \\
2\end{array}$ & $\begin{array}{l}0.39 \\
0.36 \\
0.08 \\
0.33 \\
0.18 \\
\end{array}$ \\
\hline & & & 1.34 \\
\hline $\begin{array}{ll}\text { Threats }(T) \text { : } \\
\text { - } \\
\text { - } \quad \text { Inplication of free trade (globalization) that lead to greater imported-foods } \\
\text { - } \\
\text { - } \\
\text { - Igricultural institution has not optimal } \\
\text { - Conversion communication between stakeholders } \\
\end{array}$ & $\begin{array}{l}0.14 \\
0.03 \\
0.11 \\
0.07 \\
0.12 \\
\end{array}$ & $\begin{array}{l}3 \\
1 \\
2 \\
2 \\
3 \\
\end{array}$ & $\begin{array}{l}0.42 \\
0.03 \\
0.22 \\
0.14 \\
0.24 \\
\end{array}$ \\
\hline & 1.00 & & 1.17 \\
\hline
\end{tabular}

Source: Processing Primary Data, 2018.

Threats factor of the external environment include the implementation of free trade (globalization) that increase imported-foods by the highest score 0.42 , conversion of farming land to non farming land has score 0.24 , and then the agricultural institution has not optimal by score 0.22 , ineffective communication between stakeholders has score 0.14 , and influence of the elites in the empowerment process (politic) has score 0.03 .

Total score of the strength is 1.32 and the weakness factor is 1.03 . In order to find the value of $x$, total score of the strength factor (1.32) minus total score of the weakness factor (1.03) equals 0.29 , which is so-called $x$ value. Total score 1.34 is total score of the opportunity factor, and 1.17 is total score for threat factor. So that, y value can be determined by subtracting score of the opportunity factor (1.34) and total score of the threat factor (1.17) equals 0.17 .

Based on analysis of internal and external factors along with AIE and AEE matrix, the next stage is arranging those factors in SWOT matrix. Through SWOT analysis, four cells of alternative strategy can be arranged, such as Strengths-Opportunities (SO) strategy that utilizing strength to fight for and take the opportunities, as well as Weaknesses-Opportunities (WO) strategy that minimizing weaknesses by utilizing opportunity, Strengths-Threats (ST) strategy uses strengths to overcome threats, and Weaknesses-Threats (WT) minimize weaknesses and avoid any threats. Alternative strategy of SWOT matrix.

Based on results of analysis, the selected strategy to improve social empowerment in order to achieve food security at the borders of Indonesia-Malaysia is Strengths- 
Opportunities (SO) strategy, which utilize strengths to fight for and take the opportunities, such as (1) Developing local potency-based empowerment program; (2) Developing agricultural-based industry by developing derivatives of products to increase added value; (3) Optimizing performance of the extension; (4) Increasing quantity and quality of the crop products and horticulture. According to Widjajanti (2011), in order to improve the empowerment, community should not only develop the physical capital, but also improve quality of the human resources as requirements of success in performing the empowerment.

\section{Opportunity}

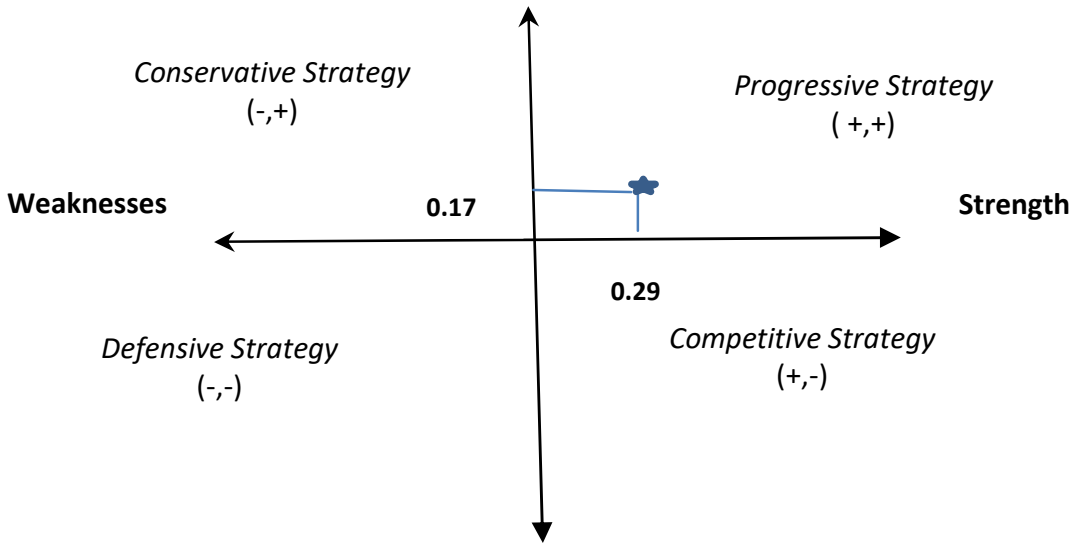

Threats

Figure 1 - Coordinates of SWOT

Table 2 - Strategic Analysis

\begin{tabular}{|c|c|c|}
\hline $\begin{array}{l}\text { ANALYSIS } \\
\text { OF EXTERNAL ENVIRONMENT } \\
\text { (AEE) }\end{array}$ & $\begin{array}{ll}\text { Strengths } \\
\text { - } & \text { Farmers produce foodstuffs } \\
\text { - } & \text { Potency of plantation and } \\
& \text { agricultural yields } \\
\text { - } & \text { Association of farmer group } \\
& \text { and GAPOKTAN } \\
\text { - } \quad \text { Wide farming land owned by } \\
\quad \text { the farmer }(>2 \mathrm{Ha}) \\
\text { - Social empowerment program } \\
\text { - } \quad \text { Agricultural extension agent } \\
\end{array}$ & $\begin{array}{l}\text { Weaknesses } \\
\text { - } \quad \text { Empowerment program has not completely } \\
\text { - } \quad \text { Incomplete infrastructural facilities of the farm } \\
\text { - } \quad \text { Foperations } \\
\text { - } \quad \text { Low participation of the farmers in social } \\
\text { - } \quad \text { Low diversification of foods } \\
\text { - } \quad \text { Low independence of the farmers } \\
\end{array}$ \\
\hline $\begin{array}{l}\text { Opportunities } \\
\text { - Utilization of the regional } \\
\text { potency has not optimal } \\
\text { and has not been } \\
\text { developed } \\
\text { - } \quad \text { Market expansion (abroad) } \\
\text { District-Owned Corporation } \\
\text { (BUMDES) } \\
\text { - Increasing needs for food } \\
\text { - Governmental assistance }\end{array}$ & $\begin{array}{l}\text { Strategy SO } \\
\text { - } \quad \text { Developing local potency- } \\
\text { based empowerment program } \\
\text { Developing agricultural-based } \\
\text { industry by developing } \\
\text { derivatives of the product to } \\
\text { enhance added value } \\
\text { Optimizing the extension } \\
\text { performance } \\
\text { Increasing quantity and quality } \\
\text { of the crops product and } \\
\text { horticulture }\end{array}$ & $\begin{array}{l}\text { Strategy WO } \\
\text { - Strengthening economic institution of the } \\
\text { farmer by establishing cooperation } \\
\text { Improving knowledge and skills of the } \\
\text { community about foods diversification through } \\
\text { extension and training } \\
\text { Improving competence of the extension agent } \\
\text { through education and training } \\
\text { Developing local foods by establishing social } \\
\text { awareness to improve food security }\end{array}$ \\
\hline $\begin{array}{l}\text { Threats } \\
\text { - } \quad \begin{array}{l}\text { Application of free trade } \\
\text { (globalization) that lead to } \\
\text { greater imported-foods } \\
\text { - } \\
\text { Influence of the elites in the } \\
\text { empowerment process } \\
\text { (politic) } \\
\text { Agricultural institution has } \\
\text { not optimal } \\
\text { Ineffective communication } \\
\text { between stakeholders } \\
\text { - Conversion of farming land } \\
\text { to non farming land }\end{array} \\
\end{array}$ & $\begin{array}{l}\text { Strategy ST } \\
\text { - Improving position of the } \\
\text { farmer through market } \\
\text { guarantee } \\
\text { Developing superior } \\
\text { commodities, which are } \\
\text { comparative and competitive, } \\
\text { particularly for crops } \\
\text { Utilizing land use in } \\
\text { accordance with layout and } \\
\text { region } \\
\text { Developing participative social } \\
\text { empowerment program } \\
\end{array}$ & $\begin{array}{l}\text { Strategy WT } \\
\text { - Designing empowerment program through } \\
\text { - } \quad \text { Imprial mapping. } \\
\text { attract the stakeholders' roles in the } \\
\text { implementation of social empowerment } \\
\text { - Integrated food policy to control the foodstuff } \\
\text { price and instability condition on subsystem of } \\
\text { food security that include availability, } \\
\text { distribution, and absorption of foods }\end{array}$ \\
\hline
\end{tabular}

Source: Processing Primary Data, 2018. 


\section{CONCLUSION AND RECOMMENDATIONS}

Analysis of internal and external factors on SWOT matrix is on quadrant I along with recommendation of the strategy Strengths - Opportunities (SO), which utilizing strength to fight for and take the opportunity.

The strategy of local resources-based social empowerment to achieve food security include: (1) Developing local potency-based empowerment program; (2) Developing agricultural-based industry by developing derivatives of the product to enhance added value; (3) Optimizing the extension performance; (4) Increasing quantity and quality of the crops product and horticulture.

The government should cooperate with the related stakeholders to facilitate the community in developing the available potency, and build the required means and infrastructures to support the achievement of food security, particularly at the borders.

\section{REFERENCES}

1. Bappeda Kabupaten Nunukan. 2017. Nunukan dalam Angka. Nunukan.

2. Effendi A.D, Barkey, Jamil. M.H. 2014. Strategi Pengembangan Program Pemberdayaan Masyarakat pada Model Desa Konservasi di Taman Nasional Taka Bonerate. J. Sains \& Teknologi, Agustus 2014, Vol.14 No.2: 151 - 161. ISSN 1411-4674.

3. Hudayat.2011.Pengeloaan sumberdaya Alam Berbasis Kelembagaan Lokal.Jurnal Sejarah Citra Lekha, Vol. XV, No. 1 Februari 2011: 19-32.

4. Huseini, M. 1999. Mencermati Misteri Globalisasi: Menata Ulang Strategi Pemasaran Internasional Indonesia Melalui Pendekatan Resource-Based. Depok: Fisip Universitas Indonesia.

5. Jokolelono, E. (2011). Pangan dan Ketersediaan Pangan. Media Litbang Sulteng IV (2), 88-96.

6. Kasmini, Rahardjo, Nugroho, Hermawati. 2017. Sumberdaya Lokal Sebagai Dasar PerencanaanProgram Gizi Daerah Urban. Jurnal MKMI. Vol. 13 No. 1, Maret 2017. 1-11.

7. Mardikanto.2010. Model-Model Pemberdayaan Masyarakat Acuan bagi Akademisi dan Praktisi Pemberdayaan Masyarakat. Lembaga Pengembangan Pendidikan.Universitas Sebelas Maret. UNS Press. Surakarta.

8. Ristina.Lia, Subagiarta.I Wayan, Hanim.A, 2014. Strategi Peningkatan Ketahanan Pangan di Kabupaten Situbondo. JSEP Vol. 7 No. 1 Juli 2014. pp 17-23.

9. Rachman. Handewi, Ariani. Mewa.2002. KetahananPangan: Konsep, Pengukuran dan Strategi.JurnalFAE. Volume 20 No. 1, Juli 2002: 12 - 24.

10. Romer Paul. 1990. Endogenous Technological Change. Journal of Political hhijmEconomy

11. Sumodiningrat, G. 2000. Visi dan Misi Pembangunan Pertanian Berbasis Pemberdayaan. Yogyakarta: IDEA. Syabra.

12. Suharto, E. \& Yuliani. 2005. Analisis Jaringan Sosial: Menerapkan Metode Asessmen Cepat dan Partisipatif (MACPA) Pada Lembaga Sosial Lokal di Subang, Jawa Barat: http://www.policy.hu/suharto/mak-Indo4.html. Diakses pada 26 Juli 2018.

13. Suryana.Kurniasih Nia, Pudjiwati.Eko. 2017. Social Empowerment to Achieve Food Security at the Borders: A case study at North Sebatik Subdistrict of Nunukan Regency (North Kalimantan Province, Indonesia). RJOAS 10 (70), ISSN 2226-1184. Oktober 2017.

14. Widjajanti.Kesi, 2011. Model Pemberdayaan Masyarakat. Jurnal Ekonomi Pembangunan Volume 12, Nomor 1, Juni 2011: 15-27 16. 